\title{
FUNGSIONALISASI SILIKA SEKAM PADI DENGAN DIFENILAMIN UNTUK ADSORPSI POLISIKLIK AROMATIK HIDROKARBON (PHENANTRENA)
}

\author{
Rinawati ${ }^{1}$, Christian Paul Partogi Sidabalok ${ }^{1}$, R. Supriyato ${ }^{1}$, Agung Abadi Kiswandono ${ }^{1}$, \\ Diky Hidayat ${ }^{1}$ \\ ${ }^{1}$ Jurusan Kimia Fakultas Matematika dan Ilmu Pengetahuan Alam Universitas Lampung \\ Jl. Sumantri Brodjonegoro No. 1 Bandar Lampung 35145
}

rinawati@fmipa.unila.ac.id

\begin{tabular}{|l|}
\hline Artikel Info \\
Diterima \\
tanggal \\
12.12 .2018 \\
Disetujui \\
publikasi \\
tanggal \\
30.04.2019 \\
Kata kunci : \\
adsorpsi, PAH, \\
Silika, sekam \\
padi
\end{tabular}

ABSTRAK

Phenantrena merupakan polutan organik yang termasuk dalam kelompok senyawa polisiklik aromatik hidrokarbon (PAH) dengan toksisitas tinggi, persisten, mutagenik dan karsinogenik. Karena itu diperlukan metode yang efisien, mudah dan ramah lingkungan untuk penyisihan senyawa polutan tersebut. Dalam penelitian ini telah dilakukan sintesis silika yang difungsionalisasikan dengan difenilamin (DPA) untuk mengadsorpsi phenantrena. Karakterisasi silikaDPA dilakukan dengan menggunakan SEM dan FTIR. Optimasi adsorpsi dilakukan berdasarkan pengaruh massa adsorben, waktu ekstraksi, pH dan konsentrasi phenantrena. Hasil karakterisasi SEM menunjukkan terbentuknya SiDPA dengan adanya perubahan morfologi pada permukaan silica dan adanya serapan spesifik gugus aromatic dan ikatan C-N pada spectrum FTIR. Hasil optimasi adsorpsi diperoleh pada massa adsorben $4 \mathrm{mg}, \mathrm{pH} 3$, waktu kontak 90 menit, dan konsentrasi larutan standar phenantrena 15,88 ppm. Adsoprsi PAH menggunakan silica sekam padi yang difungsionalisasi DPA telah berhasil dilakukan.

\begin{abstract}
Phenantrena is an organic pollutant which are included to the group of polycyclic aromatic hydrocarbons (PAHs) with high toxicity, persistent, mutagenic and carcinogenic. Therefore, an efficient, easy and environmentally friendly method is needed for the removal of these pollutant compounds. In this study silica was synthesized and functionalized with diphenylamine (DPA) to adsorb phenanthrene. Characterization of silica-DPA was carried out using SEM and FTIR. Adsorption optimization was observed based on the effect of adsorbent mass, extraction time, $\mathrm{pH}$ and phenanthrene concentration. The results of SEM characterization showed the formation of Si-DPA with morphological changes on the silica surface and the presence of specific aromatic groups and $\mathrm{C}-\mathrm{N}$ bonds in the FTIR spectrum. The results of adsorption optimization were obtained on the mass of $4 \mathrm{mg}$ adsorbent, $\mathrm{pH} 3$, contact time of 90 minutes, and the concentration of standard phenanthrene solution of $15.88 \mathrm{ppm}$. The PAH adsorption using rice husk silica that was functionalized by DPA was achieved successfully.
\end{abstract}

\section{PENDAHULUAN}

PAH adalah golongan senyawa hidrokarbon yang mempunyai dua atau lebih cincin aromatik. Golongan senyawa ini telah menjadi golongan pencemar organik yang mendapat perhatian serius karena sifatnya yang beracun, persisten, akumulatif, mutagenik dan 
karsinogenik. PAH dapat ditemukan di udara, perairan, tanah, makanan, tumbuhan dan biota lainnya. Environmental Protection Agency (US EPA) telah memasukkan PAH sebagai salah satu pencemar organik polutan utama yang berbahaya. Senyawa ini telah terdeteksi di sedimen sungai Jakarta (Rinawati and Takada, 2017), perairan Teluk Lampung (Wahyuni dkk, 2017), perairan Sungai Tiber, Italia (Montuori et al, 2016), perairan Laut CIna Selatan (Li et al, 2015). Mengingat dampak negatif yang ditimbulkan oleh PAH yang tersebar dalam berbagai media lingkungan, maka perlu dilakukan penyisihan kadar PAH dengan menggunakan metode analisis yang efisien, selektif, cepat, mudah dan ramah lingkungan.

Banyak metode yang telah dilakukan oleh para peneliti untuk menghilangkan PAH dari lingkungan, diantaranya dengan metode fisik, kimia, termal, biologi dan proses fitoremediasi yang dapat di gunakan dalam proses penghilangan kontaminasi senyawa PAH di tanah, air dan sedimen (Zhou et al, 2013;. Hu et al, 2014;. Li et al, 2014). Namun, sebagian besar metode tersebut memiliki beberapa kelemahan seperti biaya investasi yang tinggi dan pemeliharaan serta prosedur operasi yang rumit. Selain itu, beberapa proses pengolahan melepaskan produk sekunder bersifat karsinogenik dan mutagenik misalnya trihalomethanes dan asam haloacitic, suatu senyawa yang selanjutnya dapat menambahkan dampak negatif pada kesehatan manusia (Comninellis et al, 2008; Oller et al., 2011). Disisi lain metode adsorpsi untuk menghilangkan polutan telah banyak berkembang dan merupakan metode yang efektif, ekonomis dan ramah lingkungan.

Beberapa studi telah menunjukkan penggunaan berbagai material limbah pertanian yang digunakan sebagai adsorben polutan lingkungan dengan bermacam-macam kondisi (Fierro et al., 2010; Gupta and Gupta, 2015; Owabor et al., 2012; Lamichhane et al, 2016). Limbah pertanian yang berlimpah yang ada di Indonesia termasuk di ProvinsiLampung adalah sekam padi. Sebagai salah satu negara dengan makanan pokoknya beras, Indonesia telah memproduksi padi 70,85 juta ton/tahun. Jika kadar sekam padi terhadap padi sekitar 20\%, maka terdapat limbah 12,6 juta/tahun. Sekam padi merupakan material terbarukan yang kaya akan silika dan menjadi salah satu sumber material adsorben yang murah dan mudah.

Silika merupakan adsorben pendukung umum yang digunakan untuk mengadsorpsi senyawa non polar seperti PAH. Silika nanopartikel secara komersial dihasilkan dari reaksi prekursor silika seperti tetraetoksisilan (TESO) dan tetrametoksisilan (TMOS), tetapi senyawa prekursor ini mempunyai dampak negatif terhadap kesehatan dan relatif mahal (Nakashima et al, 1998; Adam et al, 2011). Karena itu pemanfaatan sumber silika lain yang lebih ramah 
lingkungan, aman dan murah seperti dari sekam padi menjadi alternatif sumber silika yang potensial.

Silika dari sekam padi digunakan sebagai adsorben karena memiliki gugus fungsi silanol yang dapat diaktivasi dengan berbagai gugus fungsi dan luas permukaan yang besar Deng et al, 2005). Untuk mengaktifkan silika sebagai adsorben PAH, maka dilakukan fungsionalisasi permukaan silika dengan mereaksikannya dengan senyawa organik yang bersifat hidrofobik sehingga diharapkan mampu mengadsorpsi secara efisien senyawa PAH yang juga bersifat hidrofobik. Ding et al (2010) menggunakan magnetit silika untuk adsorben SPE yang terfungsionalisasi dengan oktadesilfosfonit, Long et al (2012) menggunakan triphenil amin, Liu et al (2009) menggunakan C18 untuk memodifikasi permukaan silika dan Bianchi et al (2012) menggunakan diphenyl.

Berdasarkan uraian di atas, maka dalam penelitian ini dibuat silika dengan mengekstraksinya dari sekam padi yang kemudian difungsionalisasi dengan senyawa organik diphenylamin (DPA) untuk mengadsorpsi senyawa PAH. Faktor yang mempengaruhi adsorpsi seperti massa adsornen, $\mathrm{pH}$, waktu ekstraksi, dan massa adsorbat dipelajari.

\section{METODE}

\section{Alat dan Bahan}

Peralatan yang digunakan dalam penelitian ini antara lain adalah peralatan gelas, neraca analitik, oven, heating mantle, tabung eppendorf $50 \mathrm{ml}$, sentrifus, pengayak, cawan porselen, tungku pemanas (furnace), hot plate magnetic stirrer, kertas saring biasa, SEM-EDX (Scanning Electron Microscope-Energy Dispersive X-Ray), dan FTIR (Fourier Transform Infra Red). Sedangkan bahan-bahan yang digunakan dalam penelitian ini antara lain adalah sekam padi, $\mathrm{NaOH}$, DPA, etanol 96\%, larutan standar phenantrena, $\mathrm{HNO}_{3} 69 \%, \mathrm{HCl} 1 \mathrm{~N}$, metanol pro analisis (p.a), dan akuades.

\section{Prosedur}

\section{Ekstraksi silika}

Sekam padi dicuci dengan air panas hingga kotorannya hilang, kemudian direndam dalam air suling selama semalam dan dicuci dengan menggunakan air panas lagi keesokan paginya, untuk menghilangkan tanah dan kotoran. Sekam padi yang sudah bersih dikeringkan dalam oven selama semalam pada suhu $90^{\circ} \mathrm{C}$. Sekam padi yang sudah dikeringkan kemudian dimasukkan ke dalam gelas kimia $1000 \mathrm{ml}$ serta ditambah dengan larutan $\mathrm{HCl} 1 \mathrm{~N}$ selama 1 
jam, dipanaskan pada heating mantle dengan suhu $75^{\circ} \mathrm{C}$, untuk menghilangkan kotoran. Suspensinya lalu disaring dan residu sekam padi dicuci beberapa kali dengan akuades untuk menghilangkan ion-ion logam sepenuhnya. Sekam padi kemudian dikeringkan lagi selama semalam pada oven dengan suhu $90^{\circ} \mathrm{C}$. Sebanyak 40 gram sekam padi yang sudah dikeringkan dilarutkan dalam $600 \mathrm{ml} \mathrm{NaOH} 25 \%$ dalam gelas kimia $1000 \mathrm{ml}$ yang kemudian dipanaskan selama 1 jam dalam magnetic stirrer hot plate pada suhu $90^{\circ} \mathrm{C}$ untuk mengekstrak silika dari sekam padi. Hasilnya, diperoleh larutan natrium silikat setelah dilakukan penyaringan dengan menggunakan kertas saring.

\section{Presipitasi silika}

Larutan natrium silikat $100 \mathrm{ml}$ diambil dari erlenmeyer dan kemudian dimasukkan ke dalam gelas piala dan dicampurkan dengan etanol 96\% sebanyak $20 \mathrm{ml}$ dalam magnetic stirrer hot plate. Asam nitrat diteteskan secara perlahan hingga terbentuk endapan pada larutan natrium silikatnya serta diukur nilai pH nya. Endapan kemudian disentrifuse selama 5 menit pada kecepatan 4000 rpm. Pellet yang diperoleh kemudian dicuci dengan air suling dan disentrifuse lagi. Tahap ini dilakukan secara berulang kali hingga didapatkan pellet berwarna putihkeputihan. Pelletnya diletakkan pada cawan porselen dan dipanaskan selama 30 menit dalam furnace pada suhu $600^{\circ} \mathrm{C}$, serta dilakukan proses grinding untuk lebih memperhalus permukaan silika.

\section{Karakterisasi silika}

Silika yang telah diperoleh kemudian dikarakterisasi dengan menggunakan SEM-EDX (Scanning Electron Microscope-Energy Dispersive X-Ray) untuk mengetahui morfologi dan komposisi penyusun silikanya.

\section{Penyiapan adsorben}

Difenilamina sebanyak 0,08 gram sebagai gugus fungsional untuk silika dilarutkan dengan 40 $\mathrm{ml}$ aseton kemudian ditambahkan dengan 1 gram silika yang berfungsi sebagai adsorben, yang diperoleh dari perbandingan mol difenilamina dan nanosilika (1:34) (Sasithorn dkk, 2010). Campuran kemudian diagitasi dengan menggunakan stirrer pada kecepatan $250 \mathrm{rpm}$ selama 24 jam. Setelah diagitasi, dicuci dengan air suling dan kemudian dikeringkan menggunakan oven pada suhu $60^{\circ} \mathrm{C}$ selama 24 jam.

\section{Karakterisasi adsorben}

Silika dan adsorben Si-DPA nya dikarakterisasi menggunakan FTIR (Fourier Transform Infra Red) untuk mengetahui gugus fungsi apa saja yang terdapat pada silika serta untuk menguji apakah terdapat difenilamina (DPA) pada permukaan adsorben Si-DPA. 


\section{Pengujian adsorpsi}

Adapun uji adsorpsi dilakukan dengan sistem Batch dengan menguji beberapa parameter sebagai berikut :

\section{a. Pengaruh penambahan massa adsorben}

Uji adsorpsi menggunakan perbandingan penambahan jumlah adsorben dengan rentang 1-5 miligram $(1,2,3,4$, dan $5 \mathrm{mg}$ ) pada $20 \mathrm{ml}$ larutan phenantrena $10 \mathrm{ppm}$ dan dilakukan pengadukan menggunakan shaker dengan kecepatan $150 \mathrm{rpm}$ selama 60 menit pada suhu kamar. Campuran disentrifugasi dengan kecepatan 2000 rpm selama 10 menit dan filtratnya dianalisis menggunakan spektrofotometer UV-VIS untuk mengetahui konsentrasi larutan standar phenantrene sesudah proses adsorpsi.

\section{b. Pengaruh pH}

Uji adsorpsi dilakukan pada rentang pH 3-9. Massa adsorben optimum yang diperoleh dicampurkan pada $20 \mathrm{ml}$ larutan phenantrena $10 \mathrm{ppm}$ dan dilakukan pengadukan menggunakan shaker dengan kecepatan $150 \mathrm{rpm}$ selama 60 menit pada suhu kamar. Variasi $\mathrm{pH} 3,4,5,6,8$, dan 9 dilakukan dengan cara menambahkan larutan buffer masing-masing $\mathrm{pH}$ ke dalam larutan phenantrena hingga diperoleh $\mathrm{pH}$ larutan yang diinginkan. Disentrifugasi dengan kecepatan $2000 \mathrm{rpm}$ selama 10 menit dan filtratnya dianalisis menggunakan spektrofotometer UV-VIS untuk mengetahui konsentrasi larutan standar phenantrene sesudah proses adsorpsi.

\section{c. Pengaruh waktu kontak (laju adsorpsi)}

Uji adsorpsi dilakukan pada rentang waktu pengadukan 30-150 menit. Massa adsorben optimum yang diperoleh dicampurkan pada $20 \mathrm{ml}$ larutan phenantrena $10 \mathrm{ppm}$ pada $\mathrm{pH}$ optimum dan dilakukan pengadukan dengan kecepatan $150 \mathrm{rpm}$ pada variasi waktu 30, 60, 90, 120, dan 150 menit. Disentrifugasi dengan kecepatan $2000 \mathrm{rpm}$ selama 10 menit dan filtratnya dianalisis menggunakan spektrofotometer UV-VIS untuk mengetahui konsentrasi larutan standar phenantrene sesudah proses adsorpsi.

\section{d. Pengaruh konsentrasi larutan standar phenantrena}

Uji adsorpsi dilakukan dengan menambahkan kadar adsorben optimum pada 20 ml larutan standar phenantrena $1 \mathrm{ppm}, 5 \mathrm{ppm}, 10 \mathrm{ppm}$, dan $15 \mathrm{ppm}$ pada $\mathrm{pH}$ optimum dan waktu optimum. Disentrifugasi dengan kecepatan 2000 rpm selama 10 menit dan filtrat dari masingmasing larutan standar dianalisis menggunakan spektrofotometer UV-VIS untuk mengetahui konsentrasi larutan standar phenantrene sesudah proses adsorpsi.

doi: http://dx.doi.org/10.23960/aec.v4.i1.2019.p51-64 


\section{HASIL DAN PEMBAHASAN}

\section{Karakterisasi Silika Sekam Padi}

Silika yang dihasilkan dari ekstraksi sekam padi dengan metode presipitasi dapat dilihat pada Gambar 1. Silika tersebut berwarna putih dan berbentuk serbuk. Silika yang diperoleh direaksikan dengan DPA dan dikarakterisasi menggunakan SEM seperti terlihat pada Gambar 2a-2d. Dari Gambar 2a dan 2b dapat terlihat bahwa silika yang diperoleh dengan metode presipitasi sudah berbentuk spherical dan berbentuk butiran yang homogen, tetapi ukuran diameter partikel silika pada Gambar 2b masih berkisar >100 nm, sehingga dapat disimpulkan bahwa silika yang diekstrasi belum dapat digolongkan sebagai nanosilika. Sedangkan dari Gambar 2c dan 2d, dapat dilihat bahwa pemukaannya menjadi lebih bertumpuk dan menjadi lebih tidak merata antara satu dengan yang lainnya, yang disebabkan karena silikanya sudah difungsionalisasikan dengan difenilamina.

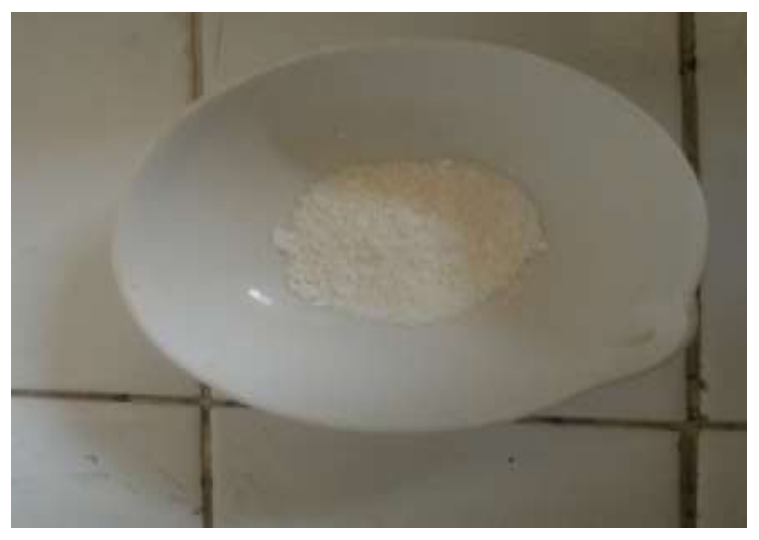

Gambar 1. Silica hasil ekstraksi

Silika yang telah diekstrak dari sekam padi dan adsorben Si-DPA yang telah disintesis kemudian dikarakterisasi menggunakan FTIR untuk mengetahui gugus fungsi apa saja yang terdapat pada silika dan adsorben Si-DPA. Hasil analisis FTIR dari silika dan adsorben SiDPA dapat dilihat pada Gambar 3a dan 3b.

Dari Gambar 3a, data spektrum menunjukkan beberapa puncak yang menunjukkan adanya beberapa gugus fungsi dalam silika, baik yang dimiliki oleh silika atau gugus fungsi yang dari pengotor yang tidak dapat dibersihkan selu- ruhnya. Puncak utama yang diyakini berkaitan dengan gugus fungsi pada silika adalah pada bilangan gelombang $3497,8 \mathrm{~cm}^{-1}$. 

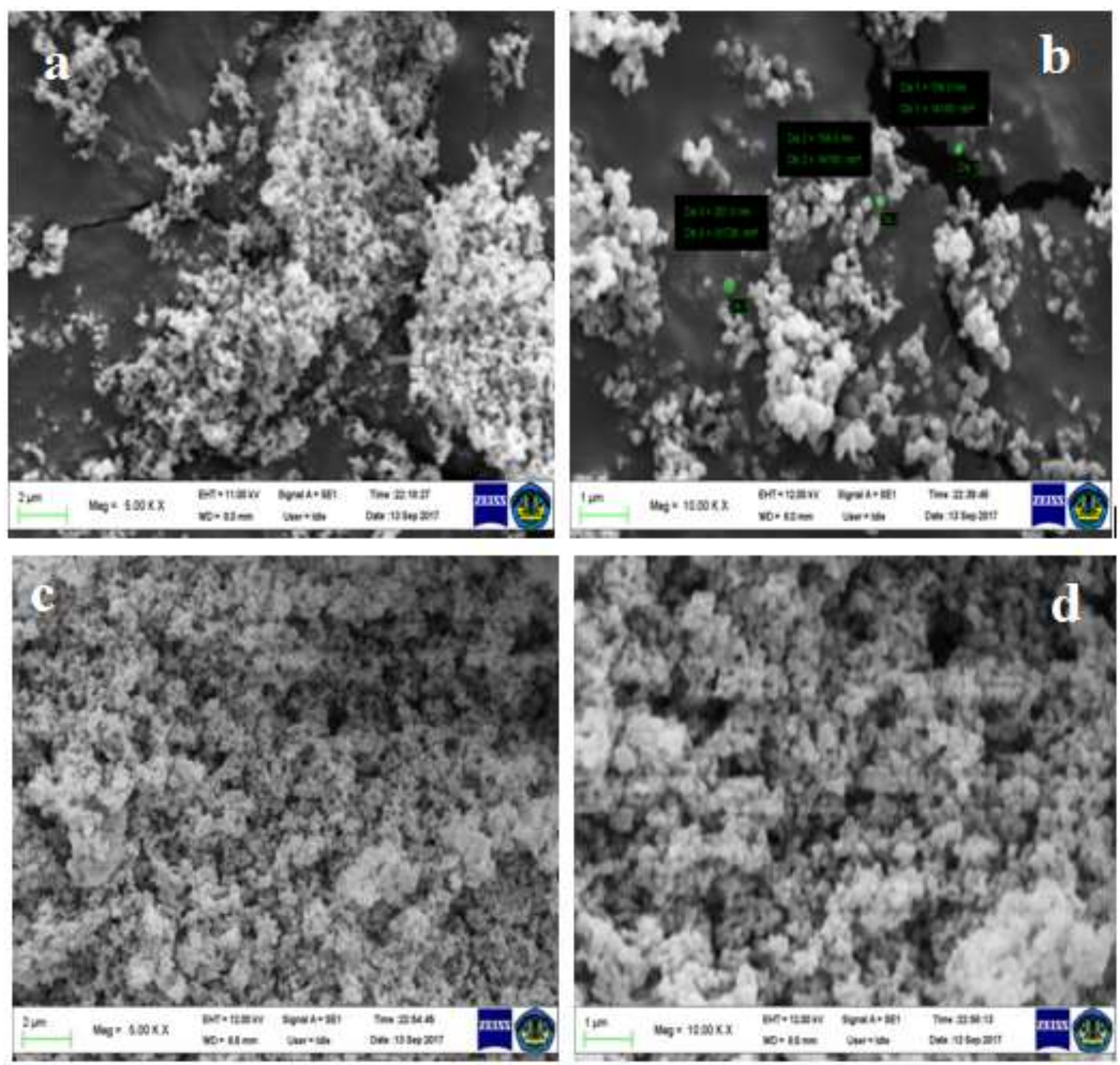

Gambar 2. a). Silika perbesaran $5000 \mathrm{x}$, b). Silika perbesaran $10000 \mathrm{x}$ dengan ukuran partikel ,c). Si-DPA perbesaran 5000 x, d). Si-DPA perbesaran 10000 x.

Puncak ini merupakan puncak yang khas untuk vibrasi ulur gugus - $\mathrm{OH}$ (gugus hidroksil). Hal ini menujukkan bahwa silika yang digunakan pada sampel mempunyai gugus hidroksil, yang menunjukkan ikatan $\mathrm{Si}-\mathrm{OH}$ (silanol). Puncak kedua yang diyakini menunjukkan gugus fungsi silika adalah puncak pada bilangan gelombang $1185,8 \mathrm{~cm}^{-1}$, yang menunjukkan adanya gugus fungsi siloksan Si-O-Si (Mor, 2016). Adanya gugus fungsi Si-OSi diperkuat dengan adanya puncak pada bilangan gelombang $475,4 \mathrm{~cm}^{-1}$, yang menunjukkan ikatan Si-O (Carmona, 2012), dan puncak pada $801,9 \mathrm{~cm}^{-1}$, yang timbul akibat vibrasi ulur asimetri ikatan Si-O dari Si-O-Si. Puncak lemah lainnya terdapat pada daerah $968,6 \mathrm{~cm}^{-1}$ (Carmona, 2012), yang menunjukkan adanya ikatan antara Si-O dengan logam. 


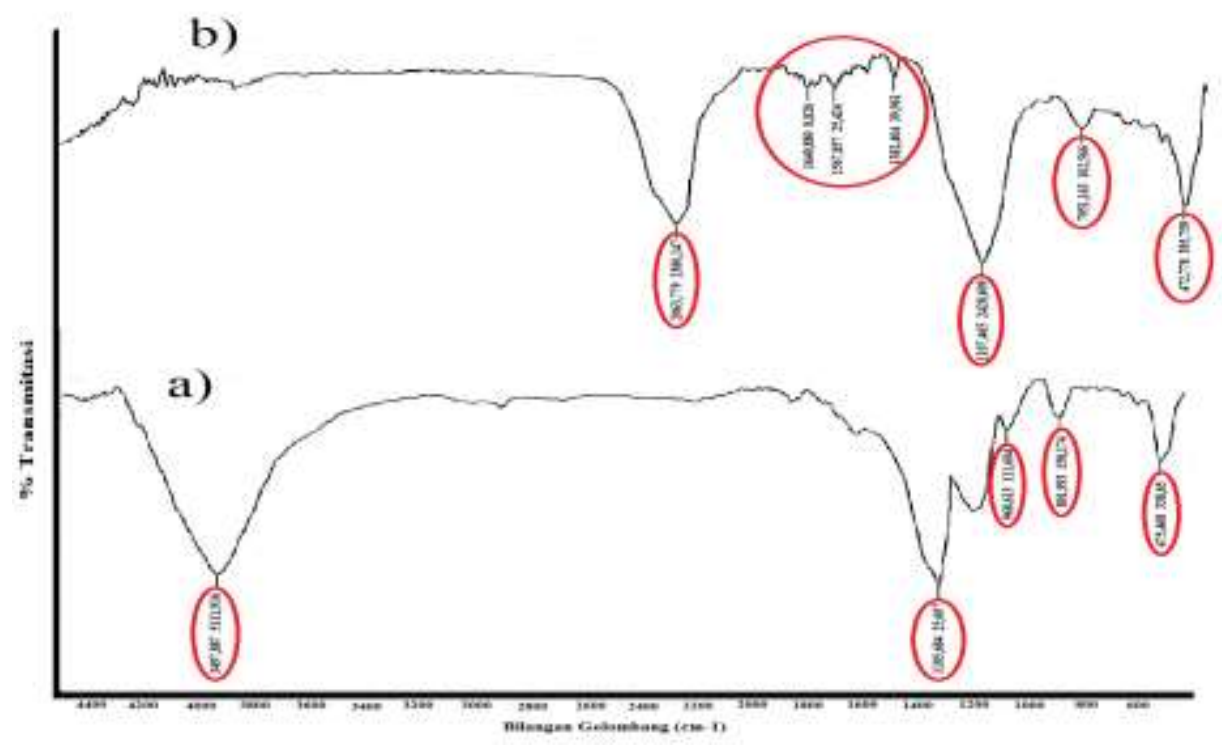

Gambar 3. Spektrum IR a). Silika, b). Si-DPA.

Pada Gambar 3b terlihat puncak dengan bilangan gelombang $1107,4 \mathrm{~cm}^{-1}$, yang menunjukkan adanya gugus fungsi siloksan Si-O-Si. Adanya gugus fungsi Si-O-Si diperkuat dengan adanya puncak pada bilangan gelombang $472,7 \mathrm{~cm}^{-1}$, yang menunjukkan ikatan Si-O. Selain itu, diperoleh bentuk spektrum sidik jari pada bilangan gelombang 1300-1700 $\mathrm{cm}^{-1}$, yang menunjukkan adanya senyawa aromatik (phenyl) yang berikatan dengan nitrogen untuk memperkuat bukti bahwa silika telah terikat dengan difenilamina dan adanya puncak pada bilangan gelombang 2063,7 $\mathrm{cm}^{-1}$, yang menunjukkan adanya ikatan C-N pada senyawa difenilamina. Dari Gambar 3a dan 3b juga terlihat adanya perbedaan yang mencolok, yaitu apabila pada Gambar 3a terdapat puncak dengan bilangan gelombang $3497,8 \mathrm{~cm}^{-1}$ yang menunjukkan adanya gugus hidroksil pada silikanya, yang menunjukkan sifat hidrofilik dari silika. Sedangkan pada Gambar 3b sudah tidak ada lagi puncak dengan bilangan gelombang $3497,8 \mathrm{~cm}^{-1}$, sehingga pada adsorben Si-DPA yang sudah disintesis dapat dipastikan tidak ada lagi gugus hidroksil, yang menyebabkan adsorben Si-DPA ini menjadi bersifat hidrofobik, sehingga dapat digunakan untuk mengadsorpsi phenantrena yang juga bersifat hidrofobik.

\section{Pengaruh penambahan massa adsorben}

Pengaruh penambahan massa adsorben terhadap phenantrene dilakukan dengan menambahan massa adsorben yang berbeda-beda $(1,2,3$, 4, dan $5 \mathrm{mg})$ yang ditambahkan ke dalam larutan phenantrene yang berfungsi sebagai adsorbat dengan konsentrasi yang sama, yaitu 10 ppm serta diaduk menggunakan shaker selama 1 jam dengan kecepatan pengadukan 
150 rpm. Hasil analisis yang diperoleh dari hubungan antara \% adsorpsi (banyaknya phenantrene yang teradsorpsi) dengan massa adsorben yang digunakan dapat dilihat pada Gambar 4.

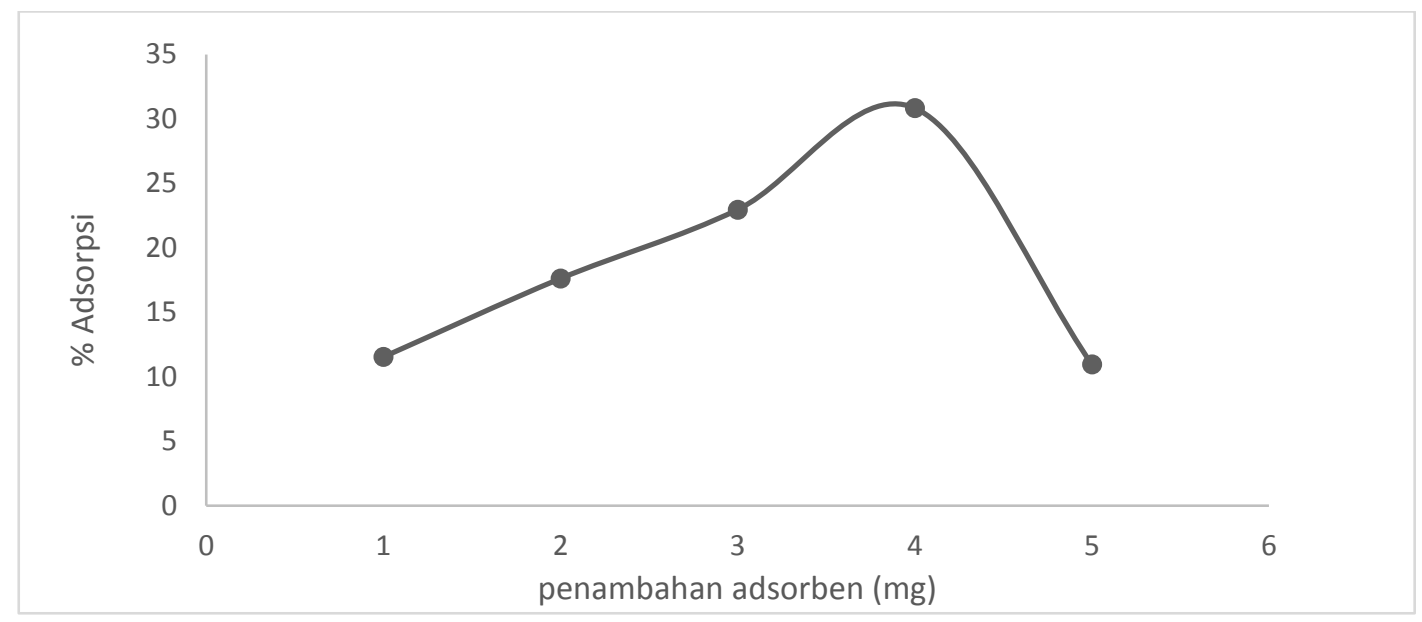

Gambar 4. Kurva hubungan antara jumlah phenantrena teradsorpsi dengan dosis adsorben Si-DPA.

Jumlah phenantrena yang terserap meningkat ketika massa adsorben yang digunakan berkisar dari 1-4 miligram pada konsentrasi larutan standar phenantrene yang tetap, akan tetapi ketika massa adsorben yang digunakan menjadi sebesar 5 miligram, jumlah phenantrena yang terserap mengalami penurunan. Hal ini mungkin disebabkan karena pada massa adsorben yang lebih besar menyebabkan terjadinya kejenuhan pada larutan standar phenantrena yang menyebabkan konsentrasi zat terlarut lebih rendah dalam larutan dibandingkan ketika massa adsorben Si-DPA lebih rendah. Dari Gambar 4, dapat diketahui bahwa dosis adsorben yang optimum digunakan untuk adsorpsi phenantrena adalah sebanyak $4 \mathrm{mg}$ dengan jumlah persen phenantrena yang teradsorpsi sebesar 31,09\%.

\section{Pengaruh pH}

Penentuan $\mathrm{pH}$ optimum adsorben dilakukan dengan cara menginteraksikan $4 \mathrm{mg}$ adsorben Si-DPA dengan larutan standar phenantrena 10 ppm yang ditambahkan dengan variasi $\mathrm{pH} 3,4,5,6,8$, dan 9, yang kemudian diaduk menggunakan shaker selama 1 jam dengan kecepatan pengadukan $150 \mathrm{rpm}$. Hasil uji adsorpsi yang diperoleh adalah pada $\mathrm{pH} 3$ diperoleh $\%$ adsorpsi tertinggi, yaitu sebesar 44,93\% seperti terlihat pada Gambar 5. 


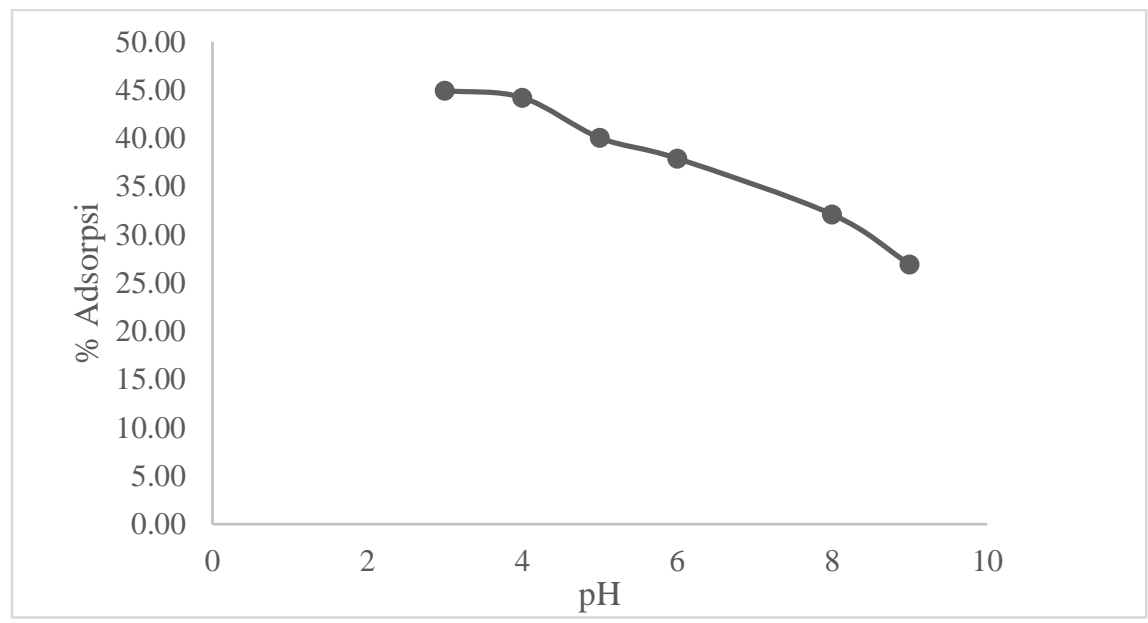

Gambar 5. Kurva hubungan antara jumlah phenantrena yang teradsorpsi dengan pengaruh $\mathrm{pH}$ pada Si-DPA.

Berdasarkan Gambar 5 dapat diamati bahwa semakin besar variasi $\mathrm{pH}$ yang digunakan pada larutan standar phenantrena, maka akan semakin sedikit jumlah phenantrena yang terserap (\% adsorpsinya mengalami penurunan seiring dengan kenaikan $\mathrm{pH}$ ). Dari hasil yang diperoleh dapat dijelaskan berdasarkan derajat ionisasi dari adsorbat dan muatan permukaan dari adsorben. Gugus fungsi dari permukaan adsorbennya adalah difenilamina yang bersifat basa, sehingga semakin rendah $\mathrm{pH}$ (semakin tinggi konsentrasi $\mathrm{H}^{+}$) pada adsorbat (larutan standar phenantrena) akan meningkatkan penyerapan karena ikatan elektrostatik antara permukaan adsorben Si-DPA yang bersifat basa (banyak mengandung gugus $\mathrm{OH}^{-}$) dan ion adsorbat (phenantrena) menjadi lebih besar (Sasithorn dkk, 2010).

\section{Pengaruh waktu kontak (laju adsorpsi)}

Laju adsorpsi antara adsorben terhadap phenantrena bertujuan untuk menentukan kondisi optimum interaksi dari larutan standar phenantrena dan keadaan kesetimbangannya terhadap adsorben Si-DPA. Penentuan waktu optimum adsorpsinya dilakukan dengan cara menginteraksikan $4 \mathrm{mg}$ Si-DPA dengan larutan standar phenantrena $10 \mathrm{ppm} \mathrm{pH} \mathrm{3,} \mathrm{diaduk}$ menggunakan shaker selama 1 jam dengan kecepatan pengadukan $150 \mathrm{rpm}$. Hasil adsorpsi phenantrena oleh adsorben Si-DPA yang didasarkan pada interaksi waktu pengadukan menggunakan shaker dapat dilihat pada Gambar 6.

Pada plot jumlah phenantrena teradsorpsi terhadap waktu kontak (Gambar 6) menunjukkan bahwa adsorpsi phenantrena oleh adsorben mengalami kenaikan mulai dari waktu 30-90 menit dan mengalami penurunan pada waktu kontak 120 dan 150 menit. Sehingga diperoleh waktu kontak optimum pada waktu 90 menit dengan jumlah phenantrena teradsorpsi sebesar 49,44\%. Pada waktu 120 dan 150 menit adsorpsi mengalami penurunan yang mungkin 
disebabkan karena interaksi antara adsorben dengan adsorbatnya menjadi jenuh, yang akan mengakibatkan phenantrenenya terdesorpsi kembali.

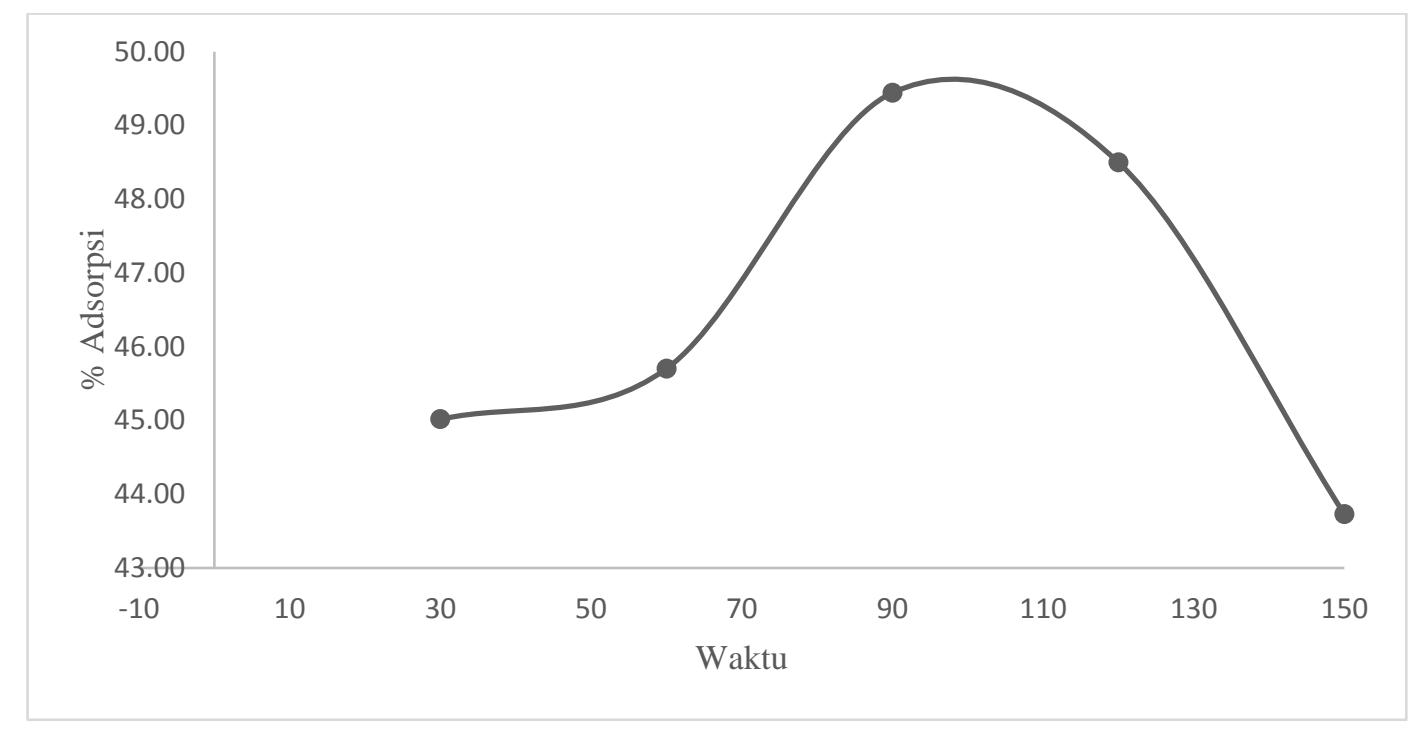

Gambar 6. Kurva pengaruh waktu kontak pada adsorpsi phenantrena oleh Si-DPA.

\section{Pengaruh konsentrasi larutan standar phenantrena}

Pengaruh konsentrasi larutan standar phenantrena yang teradsorpsi pada adsorben SiDPA dipelajari dengan menentukan pola adsorpsi. Isoterm adsorpsi ditentukan dengan menggunakan larutan standar phenantrena berbeda (1,1 ppm, 5,21 ppm, 10,33, dan 15,88 ppm) terhadap adsorben Si-DPA pada massa adsorben optimum, $\mathrm{pH}$ optimum, dan waktu kontak optimum. Hubungan pengaruh variasi phenantrena yang teradsorpsi terhadap adsorben SiDPA pada variasi konsentrasi larutan phenantrena dapat dilihat pada Gambar 7.

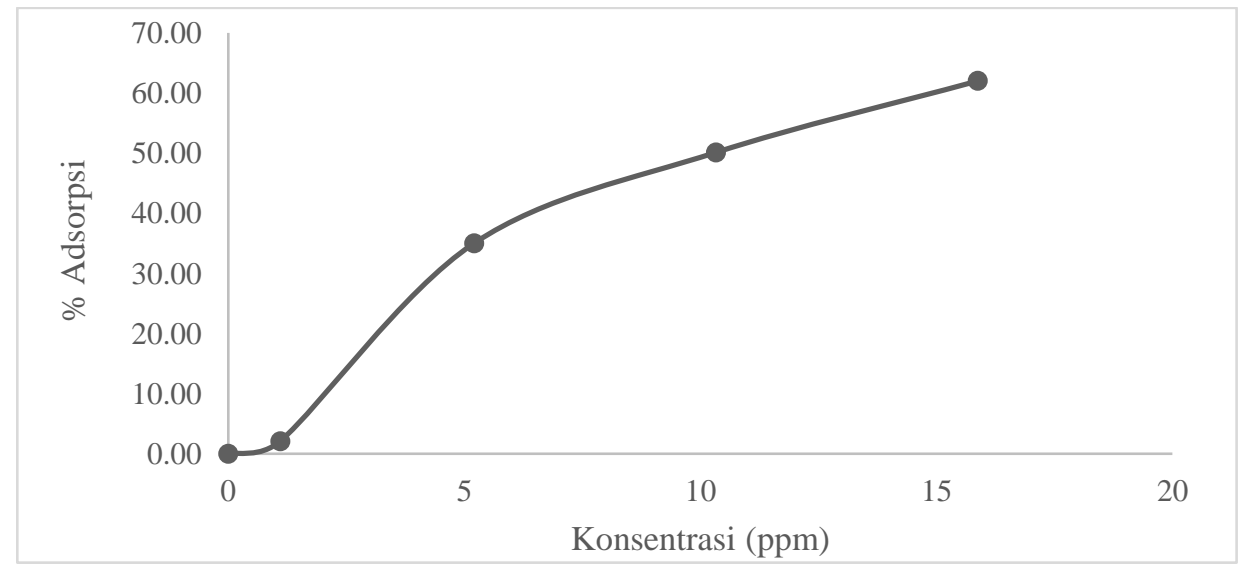

Gambar 7. Kurva hubungan antara jumlah phenantrena yang teradsorpsi dengan variasi konsentrasi phenantrena oleh Si-DPA.

doi: http://dx.doi.org/10.23960/aec.v4.i1.2019.p51-64 
Dari Gambar 7 dapat dilihat bahwa adsorpsi phenantrene pada adsorben Si-DPA mengalami kenaikan terhadap jumlah konsentrasi larutan standar phenantrene yang semakin besar. Terlihat juga bahwa jumlah phenantrena yang teradsorpsi mengalami peningkatan secara konstan dan tidak mengalami penurunan, sehingga dapat disimpulkan bahwa semakin tinggi konsentrasi larutan standar phenantrena yang digunakan, maka jumlah phenantrena yang teradsorpsinya akan semakin besar. Namun demikian, kenaikan larutan adsorbat cenderung menjadi lebih rendah pada konsentrasi tinggi dibandingkan konsentrasi awal. Hal ini masih memerlukan studi lebih lanjut maksimal larutan adsorbat yang dapat diserap.

\section{KESIMPULAN}

Sintesis adsorben Si sekam padi-DPA telah berhasil dilakukan berdasarkan hasil karakterisasi SEM-EDX dan FTIR. Adsorpsi phenantrena oleh Si-DPA optimum pada massa adsorben 4 mg, pH 3, waktu kontak 90 menit, dan konsentrasi larutan standar phenantrena 15,88 ppm. Adsorpsi phenantrena telah mencapai 62,01\% menggunakan larutan standar phenantrena $15,88 \mathrm{ppm}$.

\section{DAFTAR PUSTAKA}

Adam, F., Chew, T., Andas.,J. 2011, A simple template-free sol-gel synthesis of spherical nanosilica from agricultural biomass, J. Sol-Gel Sci Technol, Vol 59, 580-583.

Bianchi, F., Chiesi, V., Casoli, Luches, P., Nasi, L., M. Careri, L., Mangia, A., 2012, Magnetic solid-phase extraction based on diphenyl functionalization of $\mathrm{Fe}_{3} \mathrm{O}_{4}$ magnetic nanoparticles for the determination of polycyclic aromatic hydrocarbons in urine samples, Journal of Chromatography A, Vol 1231, 8- 15.

Carmona, V. B., Oliveira, R. M., Silva, W. T. L., Mattoso, L. H. C., dan Marconcini, J. M., 2012, Nanosilica from Rice Husk: Extraction and Characterization. Industrial Crops and Products, Vol. 43, 291-296.

Comninellis, C., Kapalka, A., Malato, S., Parsons, S.A., Poulios, L., Mantzavinos, D., 2008, Advanced oxidation processes for water treatment: advances and trends for R\&D. J. Chem. Technol. Biotechnol, Vol 83, 769-776.

Deng, Y.H., 2005, Investigation of formation of silica-coated magnetite nanopaticle via solgel approach, Colloids and Surface A, Vol 262, 87-93.

Ding, J., Gao, Q., Lao,D., Shi, Z., Feng, Y., 2010, n-Octadecylphosphonic acid grafted mesoporous magnetic nanoparticle: Preparation, characterization, and application in magnetic solid-phase extraction, Journal Chromatography A, Vol 1217, 7351-7358.

doi: http://dx.doi.org/10.23960/aec.v4.i1.2019.p51-64 
Fierro, Mun iz,V.G., Basta,A.H., El-Saied, H., Celzard, A., 2010, Rice straw as precursor of activated carbons: Activation with ortho-phosphoric acid, J. Hazard. Mater, Vol 181, $27-$ 34.

Gupta H. and Gupta, B., 2015, Removal of phenanthrene from water using activated carbon developed from orange rind, Int. J. Sci. Res. Environ. Sci, Vol 3, 248-255.

Hu, Y., He, Y., Wang,X., Wei, C., 2014. Efficient adsorption of phenanthrene by simply synthesized hydrophobic MCM-41 molecular sieves, Appl. Surf. Sci, Vol 311, 825-830.

Lamichhane, S., Bal Khrisna, K.C., Sarukkalige, R., 2016, Polycyclic Aromatic Hydrocarbons (PAHs) removal by sorption: A Review, Chemosphere, 148, 336-353.

Li, H., Qu, R., Li, C., Guo,W., Han, X., He, F., Ma, Y., Xing, B., 2014, Selective removal of polycyclic aromatic hydrocarbons (PAHs) from soil washing effluents using biochars produced at different pyrolytic temperatures, Bioresour. Technol, Vol 163, 193-198.

Li, P., Xue, R., Wang, Y., Zhang, R.,Zhang, G., 2015, Influence of anthropogenic activities on PAHs in sediments in a significant gulf of low-latitude developing regions, The Beibu Gulf, South China Sea: distribution, sources, inventory and probability risk, Marine Pollution Bulletin, Vol 90, 218-226.

Liu, H., Li,H., Lina, J., 2009, Magnetic solid-phase extraction based on octadecyl functionalization of monodisperse magnetic ferrite microspheres for the determination of polycyclic aromatic hydrocarbons in aqueous samples coupled with gas chromatography-mass spectrometry, Talanta, Vol 77, 1037-1042.

Long, Y., Chen, Y., Yang, F., Chen, C., Pan, Q., Cai, Q., Yao, S., 2012, Triphenylaminefunctionalized magnetic miroparticle as a new adsorbent coupled eith hing performance liquid chromatography for the analysis of trace polycyclic aromatic hydrocarbon in aqueous samples, Analyst, Vol 137, 27166-2722.

Montuori, P., Aurino, S., Garzonio, F., Sarrnachiaro, P., Nardone, A., Triassi, M., 2016, Distribution, sources and ecological risk assessment of polycyclic aromatic hydrocarbons in water and sediments from Tiber River and estuary, Italy, Science of The Total Environment, Vol 566-567, 1254-1267.

Mor, S., Chhavi K., Manchanda, Kansal, K. S., dan Ravindra, K, 2016, Nanosilica extraction from processed agricultural residue using green technology, Journal of Cleaner Production, Vol 143, 1284-1290.

Nakashima, H., Omae, K., Takebayashi, T., Isuzuka, C., Uemura, T., 1998, Toxicity of silicon compounds in semiconductor industries, Journal of Occupational Health, Vol 40 (4), 270-275.

Oller, I., Malato, S., Sanchez-Perez, J.A., 2011, Combination of advanced oxidation processes and biological treatments for wastewater decontamination-a review, Sci. Total Environ, Vol 409, 4141-4166.

Owabor, C.N., Jato, S.E.A.D, 2012, Removal of naphthalene from aqueous system using unripe orange peel as adsorbent: Effects of operating variables. Desalination and Water Treatment, Vol 48 (1), 315-319. 
Rinawati, Takada, H., 2017, Distribution and source of sedimentary Polycyclic Aromatic Hydrocarbon (PAHs) in river sediment of Jakarta, Indonesian Journal of Chemistry. Vol 17 (3), 2460-1578.

Sasithorn, J., Dawan, W., Supin, S., 2010, Utilization of fly ash from power plant for adsorption of hydrocarbon contamination in water, Journals of Metals, Materials and Minerals, Vol. 20 (1), 5-10.

Wahyuni,Y.A.D., Kiswandono, A.A., Supriyanto,R., Usman, R.P., Nasy'ah,Y., Rinawati, 2017, Identifikasi hidrokarbon polisiklik aromatic hidrokarbon (PAH) di perairan Teluk Lampung, Analit: Analytical and Envionmental Chemistry, Vol 2 (2), 57-67.

Zhou, B., W. Wang, X. Chen, C., L. Zhu, 2013, Removal of polycyclic aromatic hydrocarbons from surfactant solutions by selective sorption with organo-bentonite, Chem. Eng. J, Vol, 233, 251-257. 